\title{
ACCOUNTING STUDENTS' PERCEPTIONS AND EDUCATIONAL ACCOUNTANTS ON ETHICS OF PREPARING FINANCIAL STATEMENTS
}

\author{
Endah Nurhawaeny Kardiyati ${ }^{1}$, Abdul Karim ${ }^{2}$ \\ Faculty of Economics, University of Muhammadiyah Cirebon ${ }^{1}$ \\ Faculty of Teacher Training and Education, Muhammadiyah University of Cirebon ${ }^{2}$ \\ Email: karim_gml81@yahoo.co.id
}

\begin{abstract}
The issue of Good Corporate Governance in Indonesia is still hotly discussed because it is considered a factor that can restore investor confidence. One of the components of Corporate Governance is the existence of transparent financial reporting. The ethics and positive attitude of Indonesian accountants as the point of emphasis of this study are one of the factors for improving the quality of financial reporting. This study used a purposive sampling method and obtained two groups of samples, accounting students and teaching accountants at public and private universities in the city of Semarang. The technical analysis to test the hypothesis using non-parametric statistics Kruskal Wallis. The results of hypothesis testing show that there is no difference between public accounting firm auditors, accounting students, and educating accountants regarding the attributes of knowledge, problem-solving skills, past experiences, responsiveness to situations, self-confidence, adaptability, having relevant knowledge, being able to be responsible and able to think fast. Meanwhile, the attributes of communication skills and thinking skills proved to be different between auditors of public accounting firms, accounting students, and teaching accountants. Overall the results of the research do not fully support the convergence theory.
\end{abstract}

Keywords: $\quad$ Convergence Theory, Professionalism, Competence

\section{Introduction}

Ethics has become an important concern of Indonesian society lately, after the occurrence of various moral degradations that have occurred among practitioners and academics, with actions in the form of corruption and other irregularities, which automatically constitutes a violation of ethics, both professional ethics and ethics in general. . One form of ethical violation that is still being questioned is the problem of earnings management, because earnings management practices are considered to be ethically ambiguous (Fischer \& Rosenzweig, 1995 in Wildan, 2009). Earnings management is the act of managers reporting the amount of profit that will maximize the personal interest and / or interests of the company, using the policy of using accounting methods (Scott, 1997). Earnings management practices can be viewed from two perspectives (Scott, 1997). The first perspective, earnings management practice is considered as an opportunistic action by managers to maximize their satisfaction. The second perspective, earnings management can be seen from the perspective of efficient contracts (efficient contracting perspective), which assumes that earnings management is a logical consequence of the principal and agent relationship. Principals will anticipate earnings management behavior through compensation or interest costs that they charge the agent.

On the other hand, financial reports are a source of information for investors as a basis for consideration in making capital market investment decisions and also as a means of management responsibility for the resources entrusted to them. This shows that financial reports 
International Journal of Economics, Business and Accounting Research (IJEBAR)

Peer Reviewed - International Journal

Vol-4, Issue-3, 2020 (IJEBAR)

E-ISSN: 2614-1280 P-ISSN 2622-4771

http://jurnal.stie-aas.ac.id/index.php/IJEBAR

are an important medium for conveying corporate disclosure (disclosure in annual reports) by company management and are an important source of information in making investors' decisions. So that financial reports that have been audited by a public accountant can be a useful basis for decision making (Karim, Faiz, et al., 2020), one way that can be taken is to create criteria for the need for certain disclosures that can include all public companies. (Baridwan, 1992: 1-6) in Subiyantoro (1996).

In Indonesia, an issue is developing along with the occurrence of several ethical violations that have occurred, whether committed by public accountants, internal accountants, or government accountants. This will not happen if every accountant and prospective accountant has adequate knowledge, understanding and can apply ethics (Karim \& Hartati, 2020) in carrying out their duties as a professional accountant. The work of an accountant must be done in a professional manner which is fully based on existing moral and ethical standards. With a professional accountant's attitude, they will be able to deal with pressures that arise from themselves or from external parties, where the ability of an accountant to be able to understand and be sensitive to ethical issues is also greatly influenced by the environment in which he is located. In this case, one of the factors that can influence the behavior of an accountant is the educational environment.

Yulianti and Fitriany (2005) and Nurita and Radianto (2008) conducted a study on the perceptions of accounting students on the ethics of preparing financial statements. The results showed that accounting students do not approve of earnings management actions more than non-accounting students. This study also found that there were no differences in views on the ethics of preparing financial reports between accounting and non-accounting students and between early and final year students. Yulianti and Fitriani's (2005) research suggests the need for changes to the accounting curriculum in Indonesia, particularly in terms of ethics and values of the accounting profession. Meanwhile, research by Nurita and Radianto (2008) shows different results from Yulianti and Fitriani (2005), namely, students who have taken ethics education have a better perception of the ethics of presenting financial statements compared to students who have not taken ethics education (Karim, Mansir, Saparudin, Tumin, \& Purnomo, 2020). However, in terms of responsibilities towards users of financial information, the two groups did not show significant

The purpose of this study is to obtain empirical evidence regarding the differences in perceptions between accounting students, teaching accountants and public accountants regarding the presentation of financial statements in terms of ethics regarding management earnings, misstatements in financial reports, disclosure of sensitive financial information to companies, and cost-benefits. Disclosing financial statement information and obtaining empirical evidence regarding the differences in perceptions of accounting students, teaching accountants and public accountants about the responsibilities of users of financial statements. Researchers assume that there are different perceptions about the code of ethics of accountants that there are differences in perceptions between accounting students and accounting lecturers on the ethics of preparing financial statements. So that it is.

\section{Method}

The purpose of this research was to determine the comparison of perceptions between student accountants and accountant educators on financial reporting. So, the type of research used in this research is research using purposive sampling method to test the hypothesis (hypothesis testing), which is research that explains phenomena in the form of relationships between variables (causal research).

The populations in this research were accounting students at universities in West Java, teaching accountants (permanent accounting lecturers) and public accountants as auditors who worked in public accounting firms in West Java. The reason why the West Java region was chosen as the research location was because there was no similar research conducted in the 
International Journal of Economics, Business and Accounting Research (IJEBAR)

Peer Reviewed - International Journal

Vol-4, Issue-3, 2020 (IJEBAR)

E-ISSN: 2614-1280 P-ISSN 2622-4771

http://jurnal.stie-aas.ac.id/index.php/IJEBAR

West Java region. The minimum sample size to be studied for each respondent group is 30 people, this is in accordance with the rules of thumb proposed by Roscoe in Sekaran (2003). The sample selection method used was purposive sampling.

The distribution of the questionnaire to respondents was carried out in two ways, because it was related to the research locations that were scattered throughout West Java. The first method is for locations that are close to urban areas and easy to reach, data collection is carried out directly, by visiting universities and public accounting firms which are the research analysis units. The second way for locations that are far from urban areas and difficult to reach, data collection is done by sending questionnaires via POS. To ensure that the measurements used are the right measurements in this study, the researchers tested the data quality. According to Hair et al. (1998) the quality of data resulting from the use of research instruments can be evaluated through testing the reliability and validity of the data. This test is intended to determine the consistency and accuracy of data collected from the use of the instrument.

The normality test aims to test whether the data used from the results of distributing questionnaires has a normal distribution or not. To test whether the data distribution is normal or not, one of the easiest ways to see normality is to use the Kolmogorov Smirnov test. If the significance value exceeds 0.05 , the data is normally distributed. Conversely, if the significance value is less than 0.05, the data is not normally distributed. (Ghozali, 2001). Hypotheses 1, 2 and 3 were tested using the independent sample T-test analysis tool. The t-test difference test is carried out by comparing the difference between the two averages with the standard error of the difference in the mean of two independent samples or the formula can be written as follows:

\section{$\mathrm{t}=\quad$ First sample mean-Second sample mean \\ Standard error of the difference in the mean of the two samples}

The reason for using the t-test is because it is assumed that the data will be normally distributed, with the sample mean following the t distribution with a $95 \%$ confidence interval because the data used as a whole is in each hypothesis and it will be seen whether it has a different average value among accounting students, accountant educator and public accountant. The purpose of this test is to determine the t-test for equality means for both accounting students, teaching accountants and public accountants whether the same or different. To find out whether the population variance is identical or not with the following hypothesis: Ho: The population variance of the perceptions of accounting students, teaching accountants and public accountants is the same. As well as Ha: The population variance of the perceptions of accounting students, teaching accountants and public accountants is different.

\section{Result}

\section{Overview and Data Test}

Research data were collected by distributing 240 questionnaires to accounting students and lecturers at universities in West Java. Questionnaires were distributed by means of mail surveys and delivered directly to respondents. The following is a summary of sending and receiving the questionnaire:

Table 1 Details of Distribution and Return Questionnaire

\begin{tabular}{|c|l|c|}
\hline No & \multicolumn{1}{|c|}{ Explanation } & Amount \\
\hline 1 & $\begin{array}{l}\text { Questionnaires distributed directly } \\
\text { - Accounting student } \\
\text { - Accounting lecturer }\end{array}$ & 60 copies \\
$\begin{array}{l}\text { Questionnaires distributed by post } \\
\text { - Accounting student }\end{array}$ & 60 copies \\
\hline
\end{tabular}


International Journal of Economics, Business and Accounting Research (IJEBAR)

Peer Reviewed - International Journal

Vol-4, Issue-3, 2020 (IJEBAR)

E-ISSN: 2614-1280 P-ISSN 2622-4771

http://jurnal.stie-aas.ac.id/index.php/IJEBAR

\begin{tabular}{|c|l|c|}
\hline & - Accounting lecturer & 40 copies \\
\hline 2 & $\begin{array}{l}\text { Questionnaires dispensed directly are returned } \\
- \text { Accounting student } \\
- \text { Lecturer in Accounting } \\
\text { - Accounting student } \\
- \text { Lecturer in Accounting }\end{array}$ & 40 copies \\
\hline 3 & \begin{tabular}{l} 
Respon rate \\
\hline 4
\end{tabular} & 36 copies \\
\hline Percentage of questionnaires that can be processed & 20 copies \\
\hline
\end{tabular}

Source: Primary data processed in 2011

In table 1, it can be seen that the questionnaires distributed to respondents in this study were 300 questionnaires. There were 159 questionnaires collected. So the response rate in this study is 53\%. This number is considered high considering that the response rate for Indonesia is only $10 \%$ to $20 \%$ on average (Indriantoro, 1999). Of the 159 copies of the questionnaire collected, there were 10 questionnaires whose filling was incomplete so that the number of questionnaires that could be processed was only 149 questionnaires or $49.66 \%$. The profiles of 149 respondents who participated in this study are shown in table 2 as follows:

Table 2 Profile of Respondents

\begin{tabular}{|c|c|c|}
\hline Profile of Respondents & Amount & Percentage \\
\hline $\begin{array}{l}\text { - Gender : } \\
\text { College student } \\
\text { - Men } \\
\text { - Women } \\
\text { Lecturer } \\
\text { - Men } \\
\text { - Women }\end{array}$ & $\begin{array}{l}18 \\
37 \\
\\
22 \\
30\end{array}$ & $\begin{array}{l}32,72 \% \\
67,27 \% \\
42,30 \% \\
57,69 \%\end{array}$ \\
\hline $\begin{array}{l}\text { Education } \\
\text { Lecturer } \\
\text { - } \quad \mathrm{S} 1 \\
\text { - } \quad \mathrm{S} 2\end{array}$ & $\begin{array}{r}8 \\
44\end{array}$ & $\begin{array}{l}15,38 \% \\
84,62 \%\end{array}$ \\
\hline $\begin{array}{l}\text { Length of Work at KAP } \\
\text { - } \geq 1 \text { year } \\
\text { - } 2 \text { year }\end{array}$ & $\begin{array}{l}18 \\
24\end{array}$ & $\begin{array}{l}42,85 \% \\
57,14 \%\end{array}$ \\
\hline
\end{tabular}

Source: Primary data processed in 2011

Respondents who participated in this study consisted of 18 people (32.72\%) male accounting students, 37 people (67.27\%) female accounting students, 22 people (42.30\%) male accounting lecturers, 30 people $(57.69 \%)$. \%) female accounting lecturers. Respondents from 
International Journal of Economics, Business and Accounting Research (IJEBAR)

Peer Reviewed - International Journal

Vol-4, Issue-3, 2020 (IJEBAR)

E-ISSN: 2614-1280 P-ISSN 2622-4771

http://jurnal.stie-aas.ac.id/index.php/IJEBAR

lecturers with undergraduate education were 8 people $(15.38 \%)$ and $\mathrm{S} 2$ were 44 people $(84.62 \%)$, respondents from auditors with S1 education were 38 people $(90.47 \%)$ and S2 were 4 people $(9,52 \%)$ with a length of work at KAP of more than or equal to one year as many as 18 people $(42.85 \%)$ and with a length of working for 2 years as many as 24 people $(57.14 \%)$.

The results of testing the reliability and validity of the data show a fairly good level of consistency and accuracy. In the reliability test, the internal consistency of Cronbach's Alpha coefficient shows a coefficient value that is less than the minimum limit value of 0.60 (Nunnally, 1967 in Ghozali, 2006). Meanwhile, the validity test with the homogeneity of the data and the correlation test between the score of each item and the total score (Pearson Correlation) shows a positive correlation and a significant level at the 0.01 level. From these results it can be interpreted that the questions that measure the ethical construct of financial reporting are valid. The results of the reliability and validity tests are presented in table 3 and table 4 below.

Table 3. Reliability Test Results

\begin{tabular}{|c|c|c|c|}
\hline No & Variable & Cronbach Alpha Value & Information \\
\hline 1 & $\begin{array}{c}\text { Preparation ethics of Financial } \\
\text { Statements }\end{array}$ & Reliable \\
\hline
\end{tabular}

Source: Primary data processed in 2011

Tabel 4. Validity Test Result

\begin{tabular}{|c|l|c|c|}
\hline No & \multicolumn{1}{|c|}{ Variable } & \multicolumn{1}{|c|}{$\begin{array}{c}\text { Range } \\
\text { Correlation }\end{array}$} & Information \\
\hline 1 & $\begin{array}{l}\text { Preparation ethics of Financial } \\
\text { Statements }\end{array}$ & $0,161^{*} *_{-} 0,748^{* *}$ & Valid \\
\hline
\end{tabular}

Source: Primary data processed in 2011

** significant at the 0.01 level

An overview of the research variables of ethics in the preparation of financial statements is presented in a descriptive statistical table which shows the theoretical and actual range figures, the average standard deviation can be seen in table 4.In the table above is presented the theoretical range which is the range of theoretical answer weights. designed in a questionnaire and the actual range is the smallest value to the largest value on the weight of the respondent's real answer.

If the average value of the answers for each construct in the actual range is below the average theoretical range, it can be concluded that the respondents' perceptions of the ethics variable in preparing financial statements tend to be small. If the average value of the real range is above the average theoretical range, then the respondent's perception of the ethics variable in preparing financial statements tends to be large.

Table 5 Descriptive Statistics of Student Research Variables

\begin{tabular}{|l|c|c|c|c|c|}
\hline \multirow{2}{*}{ Variable } & \multicolumn{2}{|c|}{ Theoretical } & \multicolumn{3}{c|}{ Real } \\
\cline { 2 - 6 } & Range & Mean & Range & Mean & SD \\
\hline $\begin{array}{l}\text { Preparation ethics of } \\
\text { Financial Statements }\end{array}$ & $13-91$ & 52 & $37-64$ & 50,49 & 6,209 \\
\hline
\end{tabular}

Source: Primary data processed in 2010

Based on table 5 above, the variable of ethics for preparing financial statements for students has a theoretical range weight of 13 to 91 with an average value of 52. While in the actual range, the ethics variable for preparing financial statements has a weighting range of 37 to 64 with the average value is 50.49 and the standard deviation is 6.209 . The average value of the answers to the ethics variable in the preparation of financial statements for the actual range 
International Journal of Economics, Business and Accounting Research (IJEBAR)

Peer Reviewed - International Journal

Vol-4, Issue-3, 2020 (IJEBAR)

E-ISSN: 2614-1280 P-ISSN 2622-4771

http://jurnal.stie-aas.ac.id/index.php/IJEBAR

is below the average value of the theoretical range, so it can be concluded that the perception of student respondents on the ethics variable in preparing financial statements is low.

Table 6. Descriptive Statistics of Lecturer Research Variables

\begin{tabular}{|c|c|c|c|c|c|}
\hline \multirow{2}{*}{ Variable } & \multicolumn{2}{|c|}{} & \multicolumn{3}{|c|}{ Real } \\
\cline { 2 - 6 } & Range & Mean & Range & Mean & SD \\
\hline $\begin{array}{l}\text { Preparation ethics of } \\
\text { Financial Statements }\end{array}$ & $13-91$ & 52 & $46-65$ & 55,48 & 4,012 \\
\hline
\end{tabular}

Based on table 6 above, the variable of ethics for preparing financial statements for lecturers has a theoretical range weight of 13 to 91 with an average value of 52. While in the real range, the ethics variable for preparing financial statements has a weighting range of 46 to 65 with the average value is 55.48 and the standard deviation is 4.012 . The average value of the answers to the ethics variable in the preparation of financial statements for the actual range is above the average value of the theoretical range, so it can be concluded that the perception of lecturer respondents on the ethics variable in preparing financial statements is high.

Table 7. Descriptive Statistics of Auditor Research Variables

\begin{tabular}{|l|c|c|c|c|c|}
\hline \multirow{2}{*}{ Variable } & \multicolumn{2}{|c|}{ Theoretical } & \multicolumn{3}{c|}{ Real } \\
\cline { 2 - 6 } & Range & Mean & Range & Mean & SD \\
\hline $\begin{array}{l}\text { Preparation ethics of } \\
\text { Financial Statements }\end{array}$ & $13-91$ & 52 & $47-60$ & 53,38 & 2,963 \\
\hline
\end{tabular}

Based on table 7 above, the financial statement preparation ethics variable for auditor respondents has a theoretical range weight of 13 to 91 with an average value of 52. While in the actual range, the financial statement preparation ethics variable has a weighting range of 47 to 60. with an average value of 53.38 and a standard deviation of 2.963. The average value of the answers to the ethics variable in the preparation of financial statements for the actual range is above the average value of the theoretical range, it can be concluded that the auditor respondent's perception of the ethics variable in preparing financial statements is high.

Meanwhile, the normality test aims to test whether the data used from the results of the questionnaire distribution has a normal distribution or not. The results of the normality test are presented as follows.

Table 8. Research Variable Normality Test

\begin{tabular}{|c|c|c|c|c|}
\hline Variable & K-S Value & Sig. (2-tailed) & Criteria & Conclusion \\
\hline $\begin{array}{l}\text { Preparation ethics of } \\
\text { Financial Statements }\end{array}$ & 0,943 & 0,336 & 0.05 & Normal \\
\hline
\end{tabular}

Source: Primary data processed in 2011

Based on table 8 shows the K-S value for the ethics variable of financial statement preparation is 0.943 with a significance probability of 0.336 . The K-S significance value is compared with $\alpha=0.05$, so the K-S significance value is higher than $\alpha=0.05$. Therefore, it can be concluded that the ethical variables in the preparation of financial statements are statistically distributed normally and are suitable for use as research data. The initial step of testing is to test by looking at the similarity or difference in the average value of the respondents' answers. After that, look at the similarity or difference in the value of the variance and the mean of each respondent. To accept or reject a hypothesis, refers to predetermined criteria. 
International Journal of Economics, Business and Accounting Research (IJEBAR)

Peer Reviewed - International Journal

Vol-4, Issue-3, 2020 (IJEBAR)

E-ISSN: 2614-1280 P-ISSN 2622-4771

http://jurnal.stie-aas.ac.id/index.php/IJEBAR

Table 9. Hypothesis Test of Accounting Students \& Accounting Lecturers

\begin{tabular}{|c|c|c|c|c|c|c|c|c|c|c|}
\hline \multirow{4}{*}{$\begin{array}{c}\text { Variabele } \\
\text { Preparation } \\
\text { ethics of } \\
\text { Financial } \\
\text { Statements }\end{array}$} & \multirow[t]{2}{*}{ Respondent } & \multirow[t]{2}{*}{$\mathbf{N}$} & \multirow[t]{2}{*}{ Mean } & \multirow[t]{2}{*}{$\begin{array}{l}\text { Deviation } \\
\text { Standard }\end{array}$} & \multicolumn{2}{|c|}{ Levene Test } & \multirow[t]{2}{*}{ Assumption } & \multicolumn{2}{|r|}{ T-test } & \multirow[t]{2}{*}{$\begin{array}{l}\text { Acceptance } \\
\text { Hypothesis }\end{array}$} \\
\hline & & & & & $\bar{F}$ & Sig & & $t$ & Sig (2-tailed) & \\
\hline & Students & 55 & 50,49 & 6,209 & \multirow{2}{*}{8,054} & \multirow{2}{*}{0,005} & \multirow{2}{*}{$\begin{array}{c}\text { Equal variances } \\
\text { not assumed }\end{array}$} & \multirow{2}{*}{ 4,964 } & \multirow{2}{*}{0,000} & \multirow{2}{*}{ ACCEPTEED } \\
\hline & Dosen & 52 & 55,48 & 4,012 & & & & & & \\
\hline
\end{tabular}

Source: primary data processed (output SPSS 16) 2011

The perception of Accounting Students and Accounting Lecturers on Ethics of Financial Statement Preparation.

H1: There are differences in perceptions between accounting students and accounting lecturers on the ethics of preparing financial reports.

From table 9, it can be seen that the average answer for accounting student respondents is 50.49, while accounting lecturers are 55.48. In absolute terms it is clear that the mean is not the same between accounting student respondents and accounting lecturer respondents. The $F$ value of the levene test count is 8,054 with a probability of 0.005 . Because the probability is $0.005<0.05$, it can be concluded that the two variants are not the same so that it uses the assumption of equal variances not assumed.

Because the variants are not the same, the t-test difference analysis must use the assumption of equal variances not assumed of $-4,964$ with a significance probability of 0,000 (two tail). Because the probability is $0.000<0.05$, it can be concluded that statistically the two means (mean) are significant differences between accounting student respondents and accounting lecturer respondents. From the test results above, it can be concluded that H1 is accepted. The reason is because, statistically, the significance of the t value of 0.000 is smaller than $\alpha=0.05$. This indicates that there are differences in perceptions between the respondent group of accounting students and accounting lecturers on the ethics of preparing financial statements.

The discussion of the results of the study on the difference in perceptions between student accountants and accountant educators on financial reporting is as follows: the testing of the three (three) hypotheses proposed in this study succeeded in accepting the 3 existing hypotheses (H1). The following discussion aims to explain theoretically and empirically support the results of hypothesis testing.

The results of hypothesis testing indicate that $\mathrm{H} 1$ is accepted. It can be seen statistically that the significance of the $t$ value is 0.000 which is smaller than $\alpha=0.05$. These results indicate that there is a significant difference in perceptions between the respondent group of accounting students and accounting lecturers on the ethics of preparing financial statements. The results of hypothesis testing showed differences in ethical sensitivity between students and lecturers. The mean of student sensitivity is 50.49 while the mean for lecturers is 55.48 . This shows that the ethical sensitivity of the lecturer is higher.

Acceptance of the first hypothesis shows that accounting lecturers have a better perception than accounting students of the ethics of preparing financial statements, the results of this study are consistent with the research of Rustiana and Dian Indri (1999), which shows that the perception of teaching accountants is better than novice accountants. students) against the accountants' code of ethics. Based on the theory of moral development put forward by Kohlberg, adolescents (students) are at the conventional level, where all good and bad deeds are judged based on their goals, according to what they get during the educational process, while 
International Journal of Economics, Business and Accounting Research (IJEBAR)

Peer Reviewed - International Journal

Vol-4, Issue-3, 2020 (IJEBAR)

E-ISSN: 2614-1280 P-ISSN 2622-4771

http://jurnal.stie-aas.ac.id/index.php/IJEBAR

educating accountants (lecturers) are at the post-conventional level, where they adults interpret whether or not an act of individual rights and norms has been tested in society (Rofiah, 2010), thus between students and teaching accountants (lecturers) there will be differences in understanding of ethics, especially in the presentation of financial statements.

\section{Conclusions and Suggestions}

\section{Conclusion}

Based on the discussion that has been stated in the previous chapter, this chapter will describe the conclusions from the results of the research discussion, limitations and suggestions for developing application theory. The hypothesis $\mathrm{H} 1$ in this study is accepted, it is proven that there are differences in perceptions between accounting students and accounting lecturers on the ethics of preparing financial reports.

\section{Limitations}

The results of this study cannot be generalized to all regions in Indonesia, because the scope of this study is limited to West Java.

\section{Theoretical Implications}

Theoretically, confirmation of the results of this study as previously described, this study has implications for the development of knowledge for academics to better understand the level of sensitivity of accounting students to the ethics of preparing financial statements. The results of this study, too, will at least be an indicator of how the prospective accountants will behave professionally in the future and for the accountant groups who are respondents, this research can be used to find out how far the code of conduct has been institutionalized within each other. each group of accountants, so in general it can be said that their behavior can provide an image of an established profession and professional skills in providing increasingly meaningful services to society, resulting in a good quality audit report.

\section{Practical Implications}

This research will be able to provide information about a better understanding of the ethical development of accounting students and can provide important input in the preparation of a higher education curriculum in accounting, namely by holding the Accountant Professional Ethics course for students.

\section{Suggestion}

On the basis of the above conclusions and limitations, the following suggestions can be made: (1) Further research should expand the survey area, not only in West Java, but throughout Indonesia, so that it will better represent the population of students, lecturers and auditors throughout Indonesia. (2) It is better if further research is carried out orally (interview).

\section{References}

Agung Wibowo. 2007. Pengaruh Kode Etik Akuntan Personal Ethical Philosophy, Corporate Ethical Value Terhadap Persepsi Etis dan Pertimbangan Etis Auditor (Studi Empiris Pada kantor Akuntan Publik di Jakarta). Tesis Program Pascasarjana Magister Sains Akuntansi Universitas Diponegoro (Tidak Dipublikasikan).

Anwar, Yulianti dan Fitriany Amarullah. 2006. "Perbedaan Persepsi Mahasiswa Akuntansi Terhadap Etika Penyusunan Laporan Keuangan”. Jurnal Akuntansi dan Keuangan Indonesia. Vol. 3, No. 1. P.107-126 
International Journal of Economics, Business and Accounting Research (IJEBAR)

Peer Reviewed - International Journal

Vol-4, Issue-3, 2020 (IJEBAR)

E-ISSN: 2614-1280 P-ISSN 2622-4771

http://jurnal.stie-aas.ac.id/index.php/IJEBAR

Aprianti, Diana. 2006. Persepsi Mahasiswa Akuntansi Terhadap Lingkungan Kerja Akuntan Publik (Studi Kasus Pada Universitas Islam Indonesia). Skripsi. Yogyakarta: Universitas Islam Indonesia.

Chomariyati, Titik. 2009. "Persepsi Akuntan Pendidik dan Mahasiswa Akuntansi Terhadap Prinsip Akuntansi Berterima Umum (PABU) dan Standar Akuntansi Keuangan (SAK)". http.digilib.ucc.ac.id. diakses 25 September 2009.

Donaldson, Lex dan James H. Davis. 1991. Stewardship Theory or Agency Theory: CEO Governance and Shareholder Returns. Australian Journal of Management. Vol.16. N0.1.p 49-64.

Ghozali, Imam 2006. Aplikasi Analisis Multivariate dengan Program SPSS. Cetakan IV. Badan Penerbit Universitas Diponegoro. Semarang.

Gibson, dan James. (1993). Organisasi: Perilaku, Sturktur, Proses. Jakarta: BinarupaAksara.

Goa, J.C. \& L. Thorne, "An Introduction to the special issue on proffesionalism and ethics in Accounting Education'. Issues in Accounting Education, vol 19 (2004), pp 1-6.

Ikatan Akuntan Indonesia (IAI), 2001. Standar Profesioanal Akuntan Publik. Jakarta, Indonesia.

Indriantoro, Nur dan Supomo Bambang., 1999, Metodologi Penelitian Bisnis untuk Akuntansi dan Manajemen, BPFE - Yogyakarta.

Karim, A., Faiz, A., Parhan, M., Gumelar, A., Kurniawaty, I., Gunawan, I., ... Suanah, A. (2020). Managerial leadership in green living pharmacy activities for the development of students' environmental care in elementary schools. Journal of Critical Reviews, 7(13), 714-719. Retrieved from http://www.jcreview.com/?mno=119121.

Karim, A., \& Hartati, W. (2020). Spiritual tasks of teachers in higher order thinking skillsoriented learning. International Journal of Psychosocial Rehabilitation, 24(8), 45684580. https://doi.org/10.37200/IJPR/V24I8/PR280474.

Karim, A., Mansir, F., Saparudin, Tumin, \& Purnomo, H. (2020). Managerial leadership in boarding and public school: An idea and experience from Indonesia. Talent Development \& Excellence, 12(2), 4047-4059. Retrieved from http://iratde.com/index.php/jtde/article/view/1379.

Kombiadis, Nicholas dan John O. Okpara. 2008. Ethics and Accounting Profession: An Exploratory Study of Accounting Students In Post Secondary Institutions. International Review of Business Research Papers. Vol.4. No.5.p.147-156.

Ludigdo, Unti. 2006. “Strukturisasi Praktik Etika di Kantor Akuntan Publik”. Simposium Nasional Akuntansi IX.p1-22.

Nurita, dan Radianto, W. 2008. Persepsi Mahasiswa Akuntansi Terhadap Etika Penyusunan Laporan Keuangan. The 2nd National Conference UKWMS, (pp. 1 13). Surabaya.

Mc Carthy, I. N., "Professional Ethics Code Conflict Situations : Ethical and Value Orientation of Collegiate Accounting Students". Journal of Business Ethics, vol 16 (1997), pp $1467-1473$.

Martadi, Indiana Farid dan Suranta, S. 2006. "Persepsi Akuntan, Mahasiswa Akuntansi, dan Karyawan Bagian Akuntansi Dipandang Dari Segi Gender Terhadap Etika Bisnis dan Etika Profesi". Simposium Nasional Akuntansi IX. P.1-25

Rakhmat, Jalaluddin. (1993). Psikologi Komunikasi. Edisi Revisi. Bandung: Penerbit PT. Remaja Rosdakarya.

Robbins, Stephen P., 1996, Perilaku Organisasi: Konsep, Kontroversi, Aplikasi, Edisi Bahasa Indonesia, Jakarta: Penerbit PT. Prenhalindo,

Rofiah,.orthevie's Blog.htm, 29 Mei 2010, diakses 7 November 2010.

Rustiana dan Dian Indri, 1999. Persepsi Kode Etik Akuntan Indonesia: Komparasi Novice Accountant, Akuntan Pendidik, dan Akuntan public. Simposium Nasional Akuntansi II IAIKAPd September. 
International Journal of Economics, Business and Accounting Research (IJEBAR)

Peer Reviewed - International Journal

Vol-4, Issue-3, 2020 (IJEBAR)

E-ISSN: 2614-1280 P-ISSN 2622-4771

http://jurnal.stie-aas.ac.id/index.php/IJEBAR

Syaikhul Falah. 2006. Pengaruh Budaya Etis Organisasi dan Orientasi Etika Terhadap Sensivitas Etika (Studi Empiris tentang pemeriksaan Internal di Bawasda Pemda Papua) Tesis Program Pascasarjana Magister Sains Akuntansi Universitas Diponegoro (tidak dipublikasikan).

Scott, William R. (2003), "Financial Accounting Theory $3^{r d}$ Ed.", Prentice-Hall.

Sekaran, Uma. 2003, Research Methods For Business: A Skill-Building Approach. $4^{\text {th }}$ Edition, New York, John Wiley \& Sons Inc.

Sriwahjoeni dan Gudono. 2000. Persepsi Akuntan terhadap Kode Etik Akuntan. Jurnal Riset Akuntansi Indonesia, Vol.3, No.2, Juli, hlm.168-184.

Tim Penyusun Kamus Besar Bahasa Indonesia.1998.Kamus Besar Bahasa Indonesia Edisi Pertama, Balai Pustaka, Jakarta

Utami, Wiwik. 2005."Etika dan Pengembangan Pengajaran Akuntansi”. Buletin Penelitian Universitas Mercu Buana. Vol.8.p.1-12.

Wildan, Imam. 2009. " Persepsi etis Akuntan Pendidik dan Mahasiswa Akuntansi Terhadap Praktik Earnings Management”. imam-wildan.blogspot.com. diakses 25 September 2009.

Walgito, B. 1997. Pengantar Psikologi Umum. Yogyakarta:Andi Offset.

Winarna, Jaka dan Ninuk Retnowati, 2003, Persepsi Akuntan Pendidik, Akuntan Publik dan Mahasiswa Akuntansi terhadap Kode Etik Ikatan Akuntan Indonesia, Simposium Nasional Akuntansi VI IAI-KAPd Oktober.

Yulianti dan Fitriany. 2005. "Persepsi Mahasiswa Akuntansi Terhadap Etika penyusunan Laporan Keuangan”. Simposium Nasional Akuntansi VIII. P.791-807.

Velazquez, M.G. 2005. Business Ethics, Concept and Cases. $5^{\text {th }}$ ed.Pearson Education. Inc. Upper Saddle River. New Jersey. 